\title{
PENGGUNAAN SUBSTRAT YANG BERBEDA TERHADAP FEKUNDITAS, DERAJAT PENETASAN DAN KELANGSUNGAN HIDUP PADA PEMIJAHAN IKAN MASKOKI (Carrasius auratus)
}

\author{
The using of Different Substrate Against Fecundity, Number of Eggs, Degree of Hatching, and \\ Survival Rate On Spawning Fish of Goldfish (Carrasius auratus) \\ Yufika S ${ }^{1}$, Helmi Harris ${ }^{1}$, dan Syaeful Anwar ${ }^{2}$ \\ 1) Program Studi Perikanan Fakultas Perikanan Universitas PGRI Palembang \\ 2) Program Studi Budidaya Perikanan Fakultas Perikanan Universitas PGRI Palembang \\ Email : helmiharris76@yahoo.com
}

\begin{abstract}
Abstrak
Komoditas perikanan yang berpotensi untuk dikembangkan di Indonesia dan memiliki peluang pasar yang besar, baik di dalam maupun luar negeri salah satunya adalah komoditas ikan hias. Ikan Maskoki (Carrasius auratus) merupakan ikan hias air tawar yang banyak digemari oleh para penghobi ikan hias karena corak warnanya dan bentuk tubuh yang menarik. Ketersediaan ikan maskoki sangat ditentukan pada keberhasilan pemijahan. Cara yang dapat dilakukan untuk merangsang induk ikan Maskoki (Carrasius auratus) adalah dengan pengadaan substrat tempat meletakkan telur. Pemilihan substrat yang tepat untuk pemijahan ikan Maskoki (Carrasius auratus) masih menjadi salah satu masalah yang dihadapi oleh para pembudidaya. Untuk itu, dilakukan penelitian ini yang bertujuan untuk mengetahui jumlah telur, telur terbuahi (FR), telur menetas (HR), dan kelangsungan hidup (HR) Ikan Maskoki (Carrasius auratus) menggunakan substrat ijuk, eceng gondok, dan kombinasi antara ijuk dan eceng gondok. Penelitian dilaksanakan di UPTD Balai Benih Ikan (BBI) Gandus, Kota Palembang. Pengujian Kualitas air dilakukan di Laboratorium Lingkungan, Dinas Lingkungan Hidup Kabupaten Ogan Komering Ilir. Rancangan penelitian menggunakan Rancangan Acak Lengkap dengan 3 taraf perlakuan dan 3 ulangan. Hasil penelitian menunjukkan substrat penempatan telur ikan maskoki tertinggi diperoleh pada substrat eceng gondok dengan rata rata jumlah telur yang dihasilkan sebesar 714.67 butir telur, telur yang terbuahi berjumlah 259.10 telur dengan rata rata $86.37 \%$, jumlah telur menetas berjumlah 243.23 butir telur dengan rata rata $81.08 \%$. dan nilai kelangsungan hidup larva Ikan Maskoki (Carrasius auratus) diperoleh nilai tertinggi yaitu substrat eceng gondok berjumlah 208.30 larva dengan rata rata $69.43 \%$.
\end{abstract}

Kata Kunci: Kelangsungan Hidup, Eceng Gondok, Ijuk, Ikan Maskoki (Carrasius auratus)

\begin{abstract}
Fisheries commodities that have the potential to be developed in Indonesia and have large market oppoetunities, both at home and abroad, one of which is ornamental fish commodities. Goldfish (Carrasius auratus) are freshwater ornamental fish that are favored by ornamental fish hobbyist because of their color patterns and attractive body shape. The availability of goldfish (Carrasius auratus) is by providing a substrate on which to lay eggs. Chossing the right substrate for spawning goldfish (Carrasius auratus) is still one of the problems faced by farmer. For this reason, this study was conducted to find out the number of eggs, fertilized eggs (FR), hatched eggs (HR) and survival (SR) of goldfish (Carrasius auratus) using a palm substrate, water hyacinth, and a combination of palm and water hyacinth goiter. The research was conducted at UPTD Balai Benih Ikan Gandus, Palembang. Water quality testing is carried out at the Environmental Laboratory, Ogan Komering Ilir Regency. The study design used a completely randomized design with 3 levels of treatment and 3 reflications. The result showed the highest placement of goldfish substrate was obtained on eceng gondok substrate with average unumber of eggs produced by 714,67 eggs, fertilized amounted to 259,10 eggs with an average of 86,37\%, the number of hatched eggs amounted to 243,23 eggs with an average of 81,08\% and survival value of goldfish (Carrasius auratus) larvae obtained the highest value, is eceng gondong substrate totaling 208,30 larvae with an average of $69,43 \%$.
\end{abstract}

Keywords: Survival Rate, Eceng Gondok, Ijuk, Goldfish (Carrasius auratus) 


\section{PENDAHULUAN}

Ikan hias merupakan komoditas perikanan yang berpotensi untuk dikembangkan di Indonesia dan memiliki peluang pasar yang besar, baik di dalam maupun luar negeri. Ikan hias dari golongan genusCarrassius merupakan salah satu komoditas ikan hias air tawar yang banyak digemari oleh para penghobi ikan hias karena corak warnanya dan bentuk tubuh yang menarik, serta dapat dipelihara di kolam maupun di akuarium (Rosid et al, 2019). Salah satu jenisnya adalah Ikan Maskoki (Carrasius auratus), yang termasuk ikan air tawar yang hidup di aliran air sedang. Ikan tersebut dapat hidup di sungai, danau, waduk maupun kolam buatan. Ikan Maskoki (Carrasius auratus) dapat hidup baik pada suhu $23-29^{\circ} \mathrm{C}$, pH 6 (enam) sampai dengan 8.3, DO 4 (empat) sampai dengan 7 (tujuh) $\mathrm{mg} / \mathrm{l}$ dan amoniak 1,5 sampai dengan 4,5 mg/l (Latha dan Lipton dalam Kalsasin, 2015).

Ikan Maskoki termasuk omnivora dengan jenis pakan berupa algae, Daphnia sp, diatoms, protozoa, Rotifer, Tubifex sp, dan vegetasi (Syaifudin, Al-Noor dalam Kalsasin, 2015). Ikan Maskoki makan sesuai dengan bukaan mulut. Ikan Maskoki memiliki kebiasaan makan yang berlebihan. Pemberian pakan dapat mencapai 4-6 kali dalam sehari (Kalsasin, 2015). Menurut Abdullah (2007), pemijahan ikan Maskoki (Carrasius auratus) saat ini dilakukan secara alami, sehingga keberhasilan pemijahannya masih rendah. Kegagalan ini dipengaruhi beberapa faktor yaitu kegagalan persiapan induk yang benar-benar matang gonad dan siap dipijahkan serta kegagalan dalam merangsang induk ovulasi sehingga pemijahan yang dilakukan tidak maksimal.

Keberhasilan pemijahan ikan sangat di pengaruhi oleh beberapa faktor diantaranya penanganan induk, teknologi pemijahan khususnya dalam merangsang induk, pengeraman telur maupun penanganan larva. Cara yang dapat dilakukan untuk merangsang induk ikan Maskoki (Carrasius auratus) adalah dengan pengadaan substrat tempat meletakan telur (Penyuluhan Perikanan dan Kelautan, 2011). Pemilihan substrat yang tepat untuk pemijahan ikan Maskoki (Carrasius auratus) masih menjadi salah satu masalah yang dihadapi oleh para pembudidaya. Dengan tidak adanya pengetahuan yang baik tentang pemilihan substrat untuk pemijahan ikan Maskoki (Carrasius auratus) maka jumlah telur yang dihasilkan oleh ikan Maskoki (Carrasius auratus) tersebut menjadi tidak maksimal dan berpengaruh terhadap daya tetas telur ikan Maskoki (Carrasius auratus).

Selama ini banyak substrat yang digunakan oleh pembudidaya ikan, namun dari berapa substrat yang diberikan belum diketahui jenis substrat yang disukai oleh ikan Maskoki (Carrasius auratus) untuk meletakkan telurnya dengan maksimal. Adapun substrat yang digunakan dalam mendukung keberhasilan pemijahan ikan Maskoki (Carrasius auratus) adalah ijuk dan eceng gondok. Untuk itu dilakukan penelitian ini dengan tujuan untuk mengetahui untuk mengetahui nilai telur yang dibuahi (FR), telur yang menetas (HR) dan kelangsungan hidup (SR) Ikan Maskoki (Carrasius auratus) menggunakan substrat ijuk, eceng gondok, dan kombinasi antara ijuk dan eceng gondok.

\section{METODE PENELITIAN}

\section{Waktu dan Tempat Penelitian}

Penelitian dilaksanakan bertempat di UPTD Balai Benih Ikan (BBI) Jalan M. Amin Fauzi Soak Bujang Gandus Kota Palembang. Sedangkan pengujian kualitas air dilakukan di Laboratorium Lingkungan Dinas Lingkungan Hidup Kabupaten Ogan Komering Ilir

\section{Metode Penelitian}

Penelitian ini merupakan penelitian eksperimental, menggunakan 3 (tiga) taraf perlakuan dan 3 (tiga) ulangan, Ikan Maskoki (Carrasius auratus) yang diamati berjumlah 27 ekor, terdiri dari 9 (sembilan) betina dan 18 jantan atau perbandingannya 1 (satu) betina : 2 (dua) jantan, dengan perlakuan sebagai berikut :

P1 : Pemijahan ikan Maskoki (Carrasius auratus) menggunakan substrat eceng gondok

P2 : Pemijahan ikan Maskoki (Carrasius auratus) menggunakan substrat ijuk

P3 : Pemijahan ikan Maskoki (Carrasius auratus) menggunakan substrat kombinasi ijuk dan eceng gondok

\section{Analisis Data}

\section{a. Jumlah Telur}

Untuk mengetahui jumlah telur, digunakan rumus (Tampubolon, 2007) sebagai berikut:

$$
\mathrm{FT}=\mathrm{n} .(\mathrm{Wt} / \mathrm{Ws})
$$

Keterangan:

$\mathrm{n} \quad=$ jumlah telur yang diambil (1000)

$\mathrm{Wt}=$ berat gonad total yang ditimbang $(\mathrm{g})$

Ws $=$ berat telur 1000 yang ditimbang $(\mathrm{g})$

b. Jumlah Telur yang Dibuahi

Persentase pembuahan dihitung dengan cara membandingkan telur yang terbuahi dengan jumlah total telur kemudian dinyatakan dalam persen. (Tishom, 2008 dalam Suherman, 2016).

$$
\mathrm{FR}=\frac{\text { Jumlahtelur yang dibuahi }}{\text { Jumlahtotal telur }} \times 100 \%
$$

Keterangan:

FR $=$ Fertilization Rate (Persentase Pembuahan)

\section{c. Telur Menetas}

Menurut Murtidjo (2001) dalam Suherman (2016) daya tetas telur dapat dihitung dengan rumus : 


$$
\mathrm{HR}=\frac{\text { Jumlah telur menetas }}{\text { Jumlah telur terbuahi }} \times 100 \%
$$

Keterangan:

$\mathrm{HR}=$ Hatcing Rate (Daya Tetas Telur)

\section{d. Persentase Kelangsungan Hidup.}

Menurut Murtidjo (2001) dalam Suherman (2016), sintasan larva dapat dihitung berdasarkan rumus:

$$
\mathrm{SR}(\%)=\frac{\mathrm{Nt}}{\mathrm{No}} \times 100 \%
$$

Keterangan:

$\mathrm{SR}=$ Survival Rate

$\mathrm{Nt}=$ Jumlah larva hidup akhir pengumpulan data

No = Jumlah larva hidup awal pengumpulan data

Data yang didapatkan dianalisa secara statistika dengan mengunakan analisis keragaman (ANSIRA) untuk menentukan pengaruh perlakuan terhadap peubah yang diamati. Apabila perlakuan berpengaruh nyata atau sangat nyata maka untuk membedakan pengaruh masing masing perlakuan diuji dengan uji lanjut yang ditentukan oleh nilai koefisien keragaman (KK) perlakuan tersebut.

\section{HASIL DAN PEMBAHASAN}

\section{Jumlah Telur}

Berdasarkan hasil penelitian yang dilakukan terhadap daya tetas telur Ikan Maskoki (Carrasius auratus) dengan menggunakan substrat eceng gondok, ijuk, dan kombinasi eceng gondok dan ijuk, maka diketahui bahwa jumlah telur yang menempel pada masing-masing substrat tidak sama disetiap perlakuan, diketahui bahwa perlakuan P1 (substrat eceng gondok) diperoleh rata-rata total telur sebanyak 714,67 telur. Untuk perlakuan P2 (substrat ijuk) diperoleh rata-rata total telur sebanyak 361,67 telur dan Perlakuan P3 (substrat kombinasi eceng gondok dan ijuk)diperolehratarata total telur sebanyak 462,67 telur. Data disajikan pada Gambar 1 berikut ini

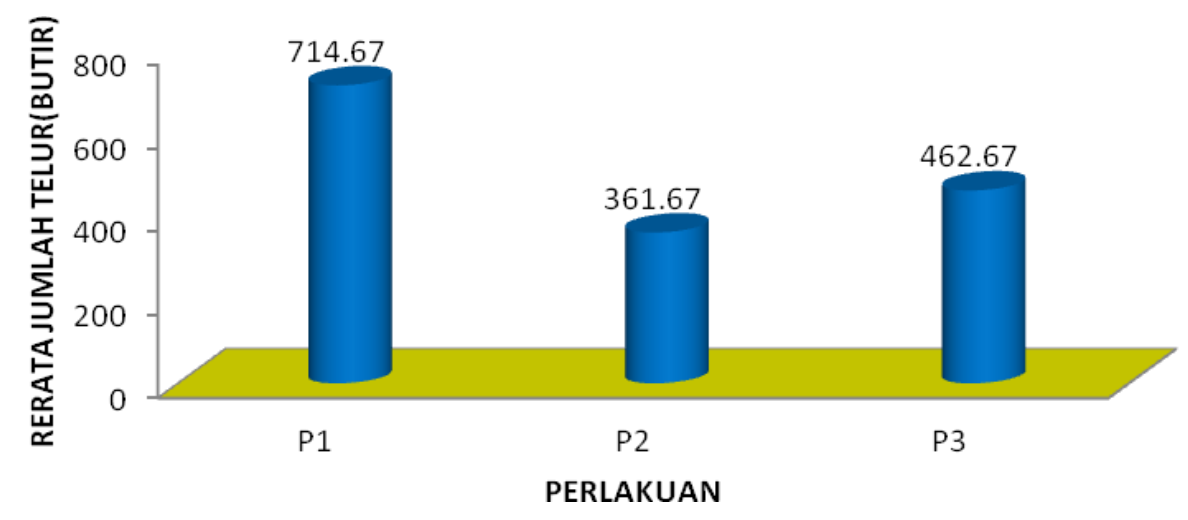

Gambar 1. Grafik Rerata Jumlah Telur Setiap Perlakuan dengan 3 (tiga) Ulangan

Analisis sidik ragam (ANSIRA) untuk mengetahui perbedaan pengaruh substrat (ijuk, eceng gondok, dan kombinasi ijuk dan eceng gondok) terhadap jumlah telur Ikan Maskoki (Carrasius auratus) diperolehbahwa nilai Fhitung sebesar 959.584 dengan nilai Ftabel untuk $\alpha=0,05$ sebesar 5.14 dan 0,01 sebesar 10.92. Dengan demikian,dapat disimpulkan bahwa ada pengaruh substrat (eceng gondok, ijuk dan kombinasi eceng gondok dan ijuk) terhadap jumlah telur Ikan Maskoki (Carrasius auratus).

Tingginya jumlah telur pada eceng gondok disebabkan akar tanaman eceng gondok yang menjulur ke dalam air akan memudahkan induk Ikan Maskoki (Carrasius auratus) untuk menempelkan telurnya. Dengan demikian jumlah telur yang dapat menempel akan lebih banyak, sehingga jumlah telur yang jatuh ke dasar akuarium dapat diminimalkan akar tanaman eceng gondok cukup lentur dan lunak sehingga dapat mencegah benturan fisik dari telur berupa luka-luka telur maupun pada tubuh induk Ikan Maskoki (Carrasius auratus) yang dipijahkan (Fajrin, 2012). Selain itu, daun tanaman eceng gondok yang cukup lebat mampu melindungi telur dari sinar matahari secara langsung karena pada fase ini telur masih peka terhadap suhu teriknya sinar matahari (Fajrin, 2012).

Hasil pengamatan sebelum pemijahan ikan lebih suka berada di substrat halus, hal ini dapat dilihat ketika induk ikan yang sudah diberok setelah dipijahkan, dan ketika induk Ikan Maskoki (Carrasius auratus) dimasukan secara bersamaan, induk Ikan Maskoki (Carrasius auratus) lebih banyak berada di dalam gumpalan akar eceng gondok dan kombinasi eceng gondok dan ijuk. Kebiasaan induk Ikan Maskoki (Carrasius auratus) setelah dimasukkan berpasangan dalam akuarium adalah induk jantan Ikan Maskoki (Carrasius auratus) lebih banyak membersihkan akar eceng gondok dan kombinasi eceng gondok dan ijuk, sedangkan induk betina Ikan Maskoki (Carrasius auratus) lebih banyak berada di akar eceng gondok tersebut dan hanya sekali-kali berada di ijuk. 
Pengamatan saat melepaskan induk Ikan Maskoki (Carrasius auratus) secara bersamaan ke dalam akuarium terlihat bahwa kesukaan induk bermain telur tidak mempengaruhi daya tetas telur. Hal ini terbukti bahwa kesukaan induk bermain di eceng gondok. Menurut Kjakson 1981 dalam Fajrin (2012) kebiasaan memijah Ikan Maskoki (Carrasius auratus) adalah ikan jantan yang secara aktif mengejar ikan betina dan membawa ikan betina kepada substrat yang telah dibersihkan ikan jantan, kemudian ikan betina akan melemparkan telur kepada substrat yang sudah bersih dan lebih padat, lalu ikan jantan mengeluarkan sperma untuk membuahi telur yang sudah lengket di substrat.

Berdasarkan hasil pengamatan juga diperoleh tinggi rendahnya jumlah telur yang menempel pada substrat dipengaruhi oleh kebersihan dan jumlah lembaran serabut tempat menempel telur, semakin banyak substrat semakin tinggi jumlah telur yang menempel, selain itu juga dipengaruhi posisi substrat. Substrat yang terjulai ke bawah lebih disukai dan mudah di tempel oleh telur. Ikan betina lebih banyak meletakkan telur pada substrat yang bersih baik bersih secara alami maupun bersih setelah di bersihkan oleh ikan jantan. Hal ini sesuai dengan pendapat Sinjal (2011), mengatakan bahwa jumlah telur ikan mas yang menempel di hydrilla sp 1.9 kali lebih banyak dari pada di kakaban (ijuk), ini disebabkan oleh perbedaan kandungan oksigen terlarut di dalam air. Kandungan oksigen di lokasi hydrilla sp lebih tinggi jika di bandingkan di lokasi ijuk. Inilah yang menyebabkan induk ikan betina lebih suka meletakkan telurnya di Hydrilla sp.

Selain faktor tersebut di atas tingginya jumlah telur pada eceng gondok juga disebabkan karena akar eceng gondok memiliki tekstur yang lembut sehingga pada saat ikan melepaskan telur dan akan menempel di substrat, telur tersebut tidak mendapatkan tekanan fisik seperti melukai telur maupun melukai induk ikan saat memijah. Liviawaty dan Afrianto (1990), menyatakan bahwa eceng gondok selain berfungsi sebagai tempat menempelkan telur, juga dapat menciptakan suasana romantik bagi Ikan Maskoki sehingga dapat mempercepat pemijahan. Selanjutnya dipertegas oleh Penyuluh Kelautan dan Perikanan (2011), bahwa tanaman eceng gondok sangat disukai Ikan Maskoki (Carrasius auratus) untuk melekatkan telur karena perakarannya mudah bergerak, rimbun dan panjang menjuntai serta bersih dan lembut. Substrat penempel telur dengan menggunakan eceng gondok (E. crassipies) memiliki nilai fertilitas tertinggi, hal ini diduga karena akar yang menjulur ke bawah, rimbun, lentur, halus, dan menggantung di dalam air memudahkan induk untuk menempelkan telurtelurnya sehingga jumlah telur yang jatuh ke dasar akuarium dapat berkurang. Selain itu substrat eceng gondok (E. crassipies) tidak menyebabkan terjadinya luka-luka pada tubuh induk ketika bergerak menempelkan telurnya pada substrat.

Penggunaan ijuk sebagai substrat penempel telur memiliki fertilitas paling rendah. Hal ini diduga karena substrat dengan menggunakan ijuk sangat kasar, sehingga Ikan Maskoki sulit untuk menempelkan telurnya pada substrat. Wahyuningsih (2012), yang menyatakan bahwa ijuk juga bersifat magnet yang dapat mengikat partikel atau pun kotoran-kotoran yang terdapat pada akuarium, dengan demikian besar kemungkinan mikrofil telur dapat dimasuki oleh pertikel ataupun tertutup dan akan sulitdimasuki oleh sperma. Inilah salah satu yang menyebabkan telur tidak terjadi pembuahan

\section{Telur Terbuahi}

Berdasarkan hasil penelitian yang dilakukan terhadap jumlah telur terbuahi Ikan Maskoki (Carrasius auratus) dengan menggunakan substrat eceng gondok, ijuk, dan kombinasi eceng gondok dan ijuk, maka diketahui bahwa jumlah telur terbuahi pada masing-masing substrat tidak sama disetiap perlakuan. Untuk perlakuan dengan substrat eceng gondok diperoleh nilai $86,37 \%$. Untuk substrat ijuk mempunyai telur terbuahi dengan nilai $84,03 \%$, sedangkan untuk substrat kombinasi eceng gondok dan ijuk mempunyai telur terbuahi diperoleh nilai $68,08 \%$. Selengkapnya disajikan pada Gambar 2 berikut ini.

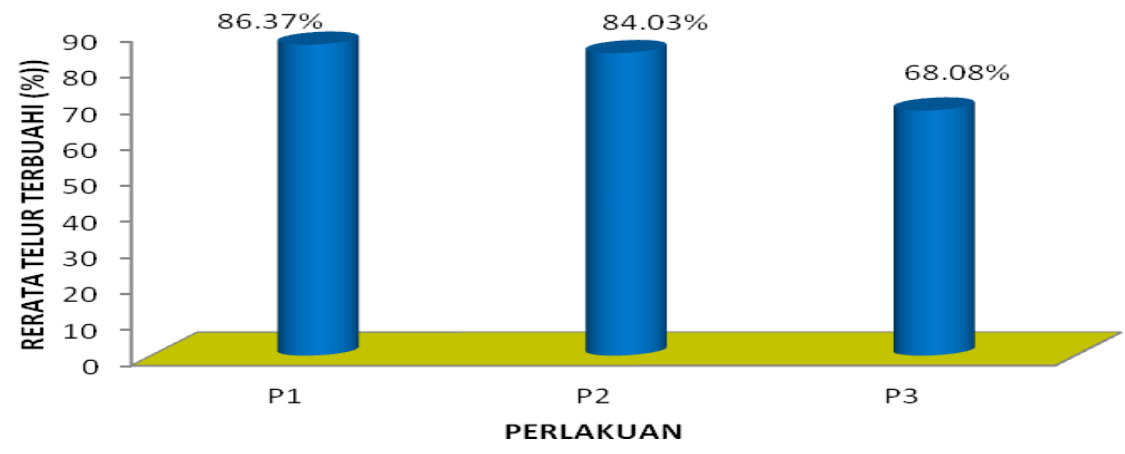

Gambar 2. Rerata Telur Terbuahi Setiap Perlakuan Dengan 3 (tiga) kali Ulangan 
Analisis sidik ragam (ANSIRA) dilakukan untuk mengetahui perbedaan substrat (ijuk, eceng gondok, dan kombinasi ijuk dan eceng gondok) berpengaruh terhadap telur terbuahi (FR). Nilai FR ikan Maskoki(Carrasius auratus) diperoleh nilai $F_{\text {hitung }}$ sebesar 1.857 dengan nilai $F_{\text {tabel }}$ untuk $\alpha=0,05$ sebesar 5.14 dan 0,01 sebesar 10.92 . Dengan demikian dapat disimpulkan bahwa substrat (eceng gondok, ijuk dan kombinasi eceng gondok dan ijuk) tidak berpengaruh terhadap telur terbuahi ikan Maskoki (Carrasius auratus) karena Fhitung lebih kecil dari Ftabel, sehingga tidak dilakukan uji lanjut.

Menurut Harvey (1979) dalam Nurfitrirahim (2013), kualitas telur yang baik dan didukung oleh kualitas air media yang memadai dapat membantu kelancaran pembelahan sel dan perkembangan telur untuk mencapai tahap akhir terbentuknya embrio ikan.Perkembangan embrio merupakan suatu kelanjutan hasil fertilisasi dari hasil sel telur dan sel sperma yang kemudian setelah dibuahi akan mengalami proses pembentukan pola-pola pembelahan telur yang disebut cleavage. Sel telur membelah secara berturut-turut hingga mencapai fase diferensiasi menjadi bentuk dewasa pada tahap organogenesis. Pertumbuhan menjadi sistem organ yang kompleks dan saling tergantung merupakan suatu hal yang terinci dalam sistem biologis yang semuanya akan termodifikasi secara sempurna

Perkembangan embrio pada ikan betina dimulai setelah telur dibuahi oleh inti spermatozoon yang semua haploid, menjadi inti zigot yang diploid. Zigot inilah yang mempunyai kemampuan untuk melakukan pembelahan segmentasi melalui proses mitosis yang cepat. Zigot yang tersegmen-segmen menjadi bagian yang kecil, bermula dari satu sel kemudian membelah menjadi 2 sel, 4 sel, 8 sel, 16 sel, hingga 32 sel yang disebut fase morula (Djuhanda, 1981 dalam Nurfitrirahim, 2013).

\section{Telur Menetas}

Berdasarkan hasil penelitian yang dilakukan terhadap telur menetas ikan Maskoki (Carrasius auratus) dengan menggunakan substrat eceng gondok, ijuk, dan kombinasi eceng gondok dan ijuk, maka diketahui bahwa jumlah telur menetas pada masing-masing substrat tidak sama disetiap perlakuan. Selengkapnya disajikan pada Gambar 3 berikut ini.

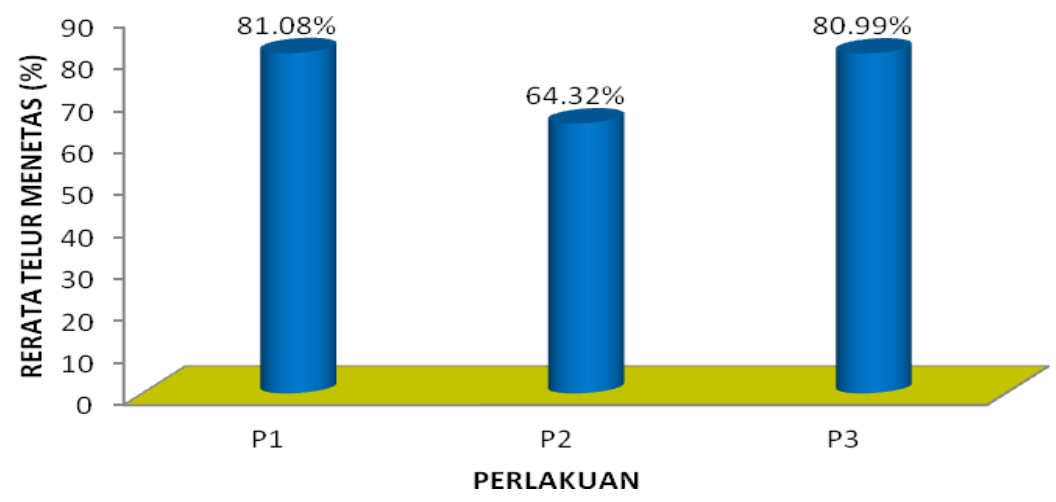

Gambar 3. Rerata telur menetas Substrat Eceng Gondok, Ijuk, dan Kombinasi Eceng Gondok dan Ijuk dengan

Dari gambar 3 di atas, menjelaskan bahwa perlakuan dengan substrat eceng gondok memberikan rerata fekunditas tertinggi dibandingkan dengan substrat ijuk maupun kombinasi eceng gondok dan ijuk. Pada subtrat eceng gondok rerata $81.08 \%$ f larva, pada subtrat ijuk rerata fekunditas sebesar $64.32 \%$ larva, dan pada rerata fekunditas subtrat kombinasi eceng gondok dan ijuk sebesar $80.99 \%$ larva. Berdasarkan perhitungan derajat penetasan, terlihat bahwa persentase penetasan tertinggi terdapat pada perlakuan eceng gondok, kemudian diikuti oleh kombinasi eceng gondok dan ijuk, dan terendah ijuk. Persentase penetasan di eceng gondok lebih tinggi dan jumlah telur di eceng gondok pun tinggi maka jumlah larva yang dihasilkan eceng gondok jauh lebih banyak.
Tinggi rendahnya derajat penetasan sangat ditentukan oleh beberapa faktor diantaranya persentase pembuahan, faktor lingkungan dan hama penyakit diduga memiliki peranan yang besar dalam menentukan derajat penetasan telur. Selain itu, diduga faktor lingkungan juga mempengaruhi seperti kualitas air, air yang kurang oksigen dan memiliki $\mathrm{pH}$ yang asam juga akan mempengaruhi daya tetas telur. Tingginya jumlah penetasan pada eceng gondok tersebut diduga akibat banyaknya telur yang terbuahi oleh sperma. Peluang telur yang lengket pada eceng gondok lebih tinggi terbuahi jika dibandingkan di ijuk, maupun kombinasi keduanya. Hal ini disebabkan oleh kerenggangan antar eceng gondok cukup luas sehingga sperma tidak mendapat hambatan oleh substrat untuk membuahi telur, sedangkan ijuk cukup padat sehingga sperma mendapat hambatan untuk 
membuahi telur. Faktor inilah yang menyebabkan rendahnya daya tetas dari substrat ijuk maupun kombinasi keduanya.

Rendahnya derajat penetasan pada ijuk dan kombinasi keduanya, selain faktor seperti di atas, juga disebabkan oleh kotornya ijuk sehingga telur diserang oleh pathogen akibatnya telur tidak bisa menetas. Menurut Widiyati (1992) telur yang telah dibuahi akan berkembang dan menetas dengan normal jika didukung oleh kondisi lingkungan yang baik, lingkungan dimaksud antara lain, kadar oksigen yang cukup, suhu yang sesuai dan air bersih yang bebas mikroorganisme yang dapat mematikan telur. Wahyuningsih (2012) juga menambahkan, rendahnya daya tetas telur pada substrat ijuk dan kombinasi eceng gondok dan ijuk diduga karena tidak semua telur yang telah dikeluarkan oleh induk Ikan Maskoki (Carrasius auratus) dapat menetas menjadi larva. Substrat ijuk bertekstur kasar dapat menghambat perkembangan embrio pada masa inkubasi telur. Hal ini sesuai pengamatan di lapangan, pada substrat ijuk, telur yang dihasilkan oleh induk Ikan Maskoki (Carrasius auratus) banyak yang jatuh pada dasar akuarium, sehingga telur tidak dapat terbuahi dengan sempurna akibatnya perkembangan embrio menjadi lemah dan telur tidak dapat menetas.

Hasil analisis sidik ragam (ANSIRA) menunjukkan bahwa Fhitung $=1.412$ lebih kecil dari Ftabel untuk $\alpha=0,05$ sebesar 5.14 dan 0,01 sebesar 10.92, maka Ho diterima, yang berarti bahwa rata-rata ketiga perlakuan tidak memberikan efek yang signifikansi terhadap daya tetas telur Ikan Maskoki (Carrasius auratus). Analisis ini menyimpulkan bahwa dari ketiga perlakuan substrat menunjukkan bahwa daya tetas telur Ikan Maskoki (Carrasius auratus) di eceng gondok lebih baik di ijuk maupun kombinasi eceng gondok dan ijuk, namun interaksi antara tiga perlakuan tersebut tidak berbeda nyata, karena telur yang terbuahi memiliki peluang menetas yang cukup besar, akan tetapi hasil penelitian jumlah telur yang terbuahi sangat rendah maka dengan demikian derajat penetasan juga menghasilkan jumlah larva sedikit.Dengan demikian, dapat disimpulkan bahwa substrat (eceng gondok, ijuk dan kombinasi eceng gondok dan ijuk) tidak berpengaruh terhadap telur yang menetas Ikan Maskoki (Carrasius auratus) karena Fhitung lebih kecil dari Ftabel.

\section{Kelangsungan Hidup}

Berdasarkan hasil penelitian yang dilakukan terhadap kelangsungan hidup Ikan Maskoki (Carrasius auratus) dengan menggunakan substrat eceng gondok, ijuk, dan kombinasi eceng gondok dan ijuk, maka diketahui bahwa kelangsungan hidup pada masing-masing substrat tidak sama disetiap perlakuan, untuk jelasnya dapat dilihat pada Gambar 4.

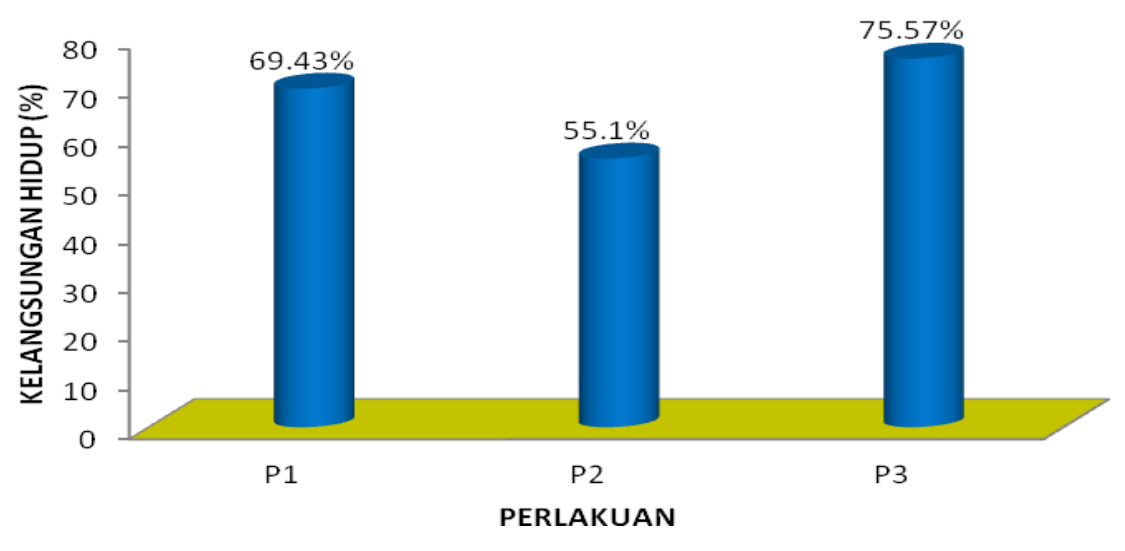

Gambar 4. Kelangsungan Hidup Larva Ikan Maskoki (Carrasius auratus) Substrat Eceng Gondok, Ijuk, Kombinasi Eceng Gondok dan Ijuk

Gambar 4 di atas menjelaskan bahwa perlakuan dengan substrat eceng gondok memberikan rerata kelangsungan hidup larva Ikan Maskoki (Carrasius auratus) tertinggi dibandingkan dengan substrat ijuk maupun kombinasi eceng gondok dan ijuk. Pada subtrat eceng gondok diperoleh rerata kelangsungan hidup larva Ikan Maskoki (Carrasius auratus) sebesar $69,43 \%$, sedangkan perlakuan kombinasi eceng gondok dan ijuk 75,57\% dan ijuk 55.10\%. Dapat diketahui juga berdasarkan perhitungan ANSIRA, bahwa nilai SR Fhitung sebesar 80.089 dengan nilai Ftabel untuk $\alpha=0,05$ sebesar 4,84 dan 0,01 sebesar 10,92. Dengan demikian, dapat disimpulkan bahwa substrat (eceng gondok, ijuk, dan kombinasi eceng gondok dan ijuk) berpengaruh terhadap kelangsungan hidup larva hari ke-14 Ikan Maskoki (Carrasius auratus).

Tingginya kelangsungan hidup pada perlakuan kombinasi eceng gondok dan ijuk diduga disebabkan oleh pengaruh padat tebar. Semakin tinggi padat tebar ikan semakin tinggi kompetisi dari makluk hidup yang ada di dalamnya, seperti kompetisi oksigen, makanan dan mudahnya mahluk hidup di serang parasit, serta mempercepat penurunan kualitas air. Rendahnya kelangsungan 
hidup pada perlakuan ijuk disebabkan oleh faktor padat tebar tinggi, sehingga kualitas air cepat menurun, oksigen berkurang, selera makan ikan rendah, sehingga ikan lemah dan mudah diserang oleh pathogen, akibatnya ikan akan lemah dan lama kelamaan akan mati.

Nurmatias (1992) mengatakan bahwa kematian ikan dipengaruhi oleh banyak faktor diantaranya kualitas air, kondisi ikan. Ikan yang lemah akibat turunnya kualitas air akan memudahkan parasit menyerang ikan tersebut.
Umumnya pada masa larva, kematian ikan disebabkan oleh makanan yang kurang tepat, kualitas air rendah sehingga menurunkan stamina ikan, akibatnya ikan mudah diserang parasit.

\section{Kualitas Air}

Nilai rerata suhu, pH, DO, dan Ammonia berdasarkan hasil uji laboratorium yang dilakukan di Laboratorium Lingkungan pada Dinas Lingkungan Hidup Kabupaten Ogan Komering Ilir disajikan pada Tabel 1 berikut ini.

Tabel 1. Hasil Pengujian Suhu, pH, DO, dan Ammonia

\begin{tabular}{clcc}
\hline No & Parameter yang Diamati & Rerata & Mutu Air Berdasarkan Pergub No. 16 Tahun 2005 \\
\hline 1 & Suhu & & \\
& Pagi & $23.85^{\circ} \mathrm{C}$ & - \\
& Siang & $26.95^{\circ} \mathrm{C}$ & - \\
\hline 2 & pH & & $6-9$ \\
& Eceng Gondok & 6.28 & \\
& Ijuk & 6.58 & $>3$ \\
& Kombinasi EG\& I & 6.92 & \\
\hline 3 & DO & & \\
& Eceng Gondok & 6.03 & \\
& Ijuk & 6.17 & \\
& Kombinasi EG\& I & 6.67 & \\
\hline
\end{tabular}

\section{a. Suhu}

Hasil pengukuran suhu air selama penelitian berkisar antara $23,85-26,95^{\circ} \mathrm{C}$. Hasil ini masih dikatakan baik dan optimal untuk kelangsungan hidup Ikan Maskoki (Carrasius auratus). Sesuai pernyataan Lingga et al (1993) yang menyatakan bahwa suhu air yang cocok untuk Ikan Maskoki (Carrasius auratus) adalah $20-25^{\circ} \mathrm{C}$, dengan perbedaan suhu pagi dan siang tidak lebih dari $5^{\circ} \mathrm{C}$. b. $\mathbf{p H}$

Hasil pengukuran rerata $\mathrm{pH}$ air untuk perlakuan eceng gondok adalah 6.28 , perlakuan ijuk adalah 6.58 dan perlakuan kombinasi eceng gondok dan ijuk adalah 6.92. Nilai tersebut masih dalam batas optimum $\mathrm{pH}$ yang sesuai untuk ikan maskoki. Rahmi et al (2012) dalam Suhendri (2018) menyatakan bahwa $\mathrm{pH}$ yang baik untuk Ikan Mas Koki berkisar 6.5 - 8.5. Wihardi et al (2014), Besarnya jumlah kotoran ikan dalam suatu perairan akan berpengaruh terhadap $\mathrm{pH}$ perairan tersebut.

c. DO

Hasil pengukuran rerata DO untuk perlakuan eceng gondok adalah 6.03, perlakuan ijuk adalah 6.17 dan perlakuan kombinasi eceng gondok dan ijuk adalah 6.67. Berdasarkan PerGub mengenai mutu air, nilai DO tersebut termasuk dalam nilai toleransi ikan maskoki. Hal ini didukung oleh pendapat Lingga et al (1993), dimana kualitas air dalam pemijahan Ikan Maskoki (Carrasius auratus) dibutuhkan DO > 3 agar memperoleh hasil yang maksimal.

\section{KESIMPULAN DAN SARAN}

\section{Kesimpulan}

Berdasarkan hasil penelitian dapat disimpulkan sebagai berikut : tempat penempatan telur ikan maskoki tertinggi diperoleh pada substrat eceng gondok dengan rata rata jumlah telur yang dihasilkan sebesar 714.67 butir telur, telur yang terbuahi berjumlah 259.10 telur dengan rata rata $86.37 \%$, jumlah telur menetas berjumlah 243.23 butir telur dengan rata rata $81.08 \%$. dan nilai kelangsungan hidup larva Ikan Maskoki (Carrasius auratus) diperoleh nilai tertinggi yaitu substrat eceng gondok berjumlah 208.30 larva dengan rata rata $69.43 \%$.

2. Saran

Dalam proses pemijahan Ikan Maskoki (Carrasius auratus) menggunakan substrat eceng gondok ,hal ini di karenakan susbtrat eceng gondok memiliki akar yang berserat halus dan menjulur ke dalam air sehingga memudahkan induk Ikan Maskoki (Carrasius auratus) untuk menempelkan telur.

\section{DAFTAR PUSTAKA}

Abdullah, N. 2007. Efektivitas Pemberian Ovaprim Secara Topikal pada Proses Ovulasi dan Pemijahan Induk Ikan Maskoki (Carassius auratus). Tesis. Sekolah Pascasarjana. Institut Pertanian Bogor. Bogor.

Fajrin C.N. 2012. Penambahan Ekstrak Tauge Dalam Pakan Untuk Meningkatkan 
Keberhasilan Pemijahan Ikan Maskoki (Carassius auratus). Jurnal Perikanan dan Kelautan. Vol 3. No 3. Fakultas Perikanan dan Ilmu Kelautan. UNPAD. Bandung.

Kalsasin, D.D. 2015. Pemanfaatan Perasan Biji Pepaya (Carica papaya) Untuk Mencegah Infestasi Argulus Pada Ikan Maskoki (Carassius auratus). Skripsi.

Lingga. 1993. Pemijahan Ikan Tawes Dengan Sistem Imbas Menggunakan Ikan Mas Sebagai Pemicu. Jurnal Akuakultur Indonesia. Vol 4. No (2). Jurusan Budidaya Perairan, Fakultas Perikanan dan Ilmu Kelautan, Institut Pertanian Bogor. Bogor.

Liviawaty, E. dan Afrianto, E. 1990. Maskoki Budidaya dan Pemasarannya. Penerbit Kanisius. Yogyakarta.

Nurfitrirahim. 2013. Laporan Perkembangan Embrio Ikan Mas.Balai Besar Pengembangan Budidaya Air Tawar. Sukabumi.

Nurmatias, 1992. Kelayakan Kualitas Air Tempat Budidaya Anguilla bicolor di Balai Besar Pengembangan Budidaya Air Tawar (BBPBAT) Sukabumi. Balai Besar Pengembangan Budidaya Air Tawar. Sukabumi.

Penyuluhan Perikanan dan Kelautan. 2011. Pembenihan Ikan Hias Maskoki (Carrasius auratus). Jakarta.

Rosid, M.M., Yusanti, I.A., Mutiara, D. 2019. Tingkat Pertumbuhan Dan Kecerahan Warna Ikan Komet (Carassius Auratus) Dengan Penambahan Konsentrasi Tepung Spirulina sp Pada Pakan. Jurnal Ilmu-ilmu
Perikanan dan Budidaya Perairan. 14(1). 3744

Sinjal, H. 2011. Pengaruh Substrat Ijuk dan Hydrilla sp. Terhadap Derajat Pembuahan dan Penetasan Telur Ikan Mas. Jurnal Perikanan dan Kelautan Tropi. Vol 7 No 1. Program Studi Budidaya Perairan. Fakultas Perikanan dan Kelautan. Universitas Ram Ratulangi Manado. Manado.

Suhendri, H., Harris, H., Utpalasari, R.L. 2018. Kombinasi Pakan Komersil dengan Cacing Darah (Chironomus sp) Terhadap Pertumbuhan, Dan Kelangsungan Hidup Ikan Mas Koki (Carrassius auratus). Jurnal Ilmu-ilmu Perikanan dan Budidaya Perairan. 13(1). 37-44

Wahyuningsih, S. 2012. Pengaruh Jenis Substrat Penempel Telur Terhadap Tingkat Keberhasilan Pemijahan Ikan Komet (Carassius auratus).Jurnal Perikanan Unram, Volume 1, No. 1. Universitas Mataram. Mataram.

Widiyati. 1992. Pengaruh Jenis Substrat Penempel Telur Terhadap Tingkat Keberhasilan Pemijahan Ikan Maskoki (Carassius auratus). Jurnal Perikanan Unram, Volume 1, No. 1. Universitas Mataram. Mataram

Wihardi, Y., Yusanti, I.A dan Haris, R.B.K. 2014. Feminisasi pada Ikan Mas (Cyprinus carpio) dengan Perendaman Ekstrak Daun-Tangkai Buah Terung Cepoka (Solanum torvum) pada lama Waktu Perendaman Berbeda. Jurnal Ilmu-ilmu Perikanan dan Budidaya Perairan. 9(1): 23 - 28 
Jurnal Ilmu-ilmu Perikanan dan Budidaya Perairan Volume 14, Nomor 2, Desember 2019 